\title{
EVALUASI KUALITAS GENETIK IKAN NILA (Oreochromis niloticus) DI BEBERAPA SENTRA BUDIDAYA DI INDONESIA
}

\section{EVALUATION OF GENETIC QUALITY OF TILAPIA (Oreochromis niloticus) IN SOME FARMING CENTERS IN INDONESIA}

\author{
Raden Roro Sri Puji Sinarni Dewi ${ }^{1 \#}$, Lies Emmawati Hadie ${ }^{2}$, Bambang Priono \\ ${ }^{1}$ Balai Riset Perikanan Budidaya Air Tawar dan Penyuluhan Perikanan \\ Jl. Sempur I, Bogor \\ ${ }^{2}$ Pusat Riset Perikanan \\ Jl. Ragunan no. 20, Pasar Minggu, Jakarta Selatan \\ E-mail: sripudjisinarni@gmail.com
}

(Diterima: 3 Desember 2020; Diterima setelah perbaikan: 14 September 2021; Disetujui: 19 September 2021)

\begin{abstract}
ABSTRAK
Studi ini dilakukan untuk mengevaluasi tingkat keragaman genetik ikan nila (Oreochromis niloticus) unggul di sentra budidaya ikan nila yang berada di Lombok, Nusa Tenggara Barat dan Purwakarta, Jawa Barat. Analisis Random Amplified Polymorphic DNA (RAPD) digunakan untuk mengestimasi heterosigositas dan polimorfisme tiga strain ikan nila unggul yang banyak digunakan di dua sentra budidaya tersebut yaitu ikan nila Nirwana I, Nirwana III, dan Anjani. Hasil penelitian menunjukkan bahwa ikan nila strain Anjani dan strain Nirwana III memiliki nilai polimorfisme ( $>60 \%$ ) dan heterosigositas yang tinggi yang mengindikasikan tingginya keragaman genetik dan kemampuan adaptasi pada kedua strain tersebut. Ikan nila strain Anjani dan Nirwana III, masih memiliki karakter unggul sebagai induk ataupun benih dan penggunaannya di masyarakat dapat terus dilanjutkan. Adapun pada ikan nila strain Nirwana I, menunjukkan nilai polimorfisme yang rendah $(<60 \%)$ dan heterosigositas yang rendah, diduga sebagai akibat tingginya tingkat inbreeding pada strain tersebut. Dampak dari rendahnya tingkat keragaman genetik diantaranya adalah penurunan kecepatan tumbuh strain ikan nila tersebut sehingga tidak direkomendasikan digunakan sebagai induk unggul di masyarakat.
\end{abstract}

KATA KUNCI: Evaluasi genetic; Oreochromis niloticus; RAPD; sentra budidaya

\begin{abstract}
This study was conducted to evaluate the level of genetic diversity of superior tilapia (Oreochromis niloticus) in tilapia aquaculture centers located in Lombok, West Nusa Tenggara and Purwakarta, West Java. Random Amplified Polymorphic DNA (RAPD) analysis was used to estimate the heterozygosity and polymorphism of the three strains of superior tilapia that are widely used in the two farming centers, namely Nirwana I, Nirwana III, and Anjani tilapia. The results showed that the tilapia strain Anjani and Nirwana III strains had high polymorphism (>60\%) and heterozygosity values which indicated high genetic diversity and adaptability in both strains. Tilapia, strain Anjani and Nirwana III, still have superior character as broodstock or seed and their use for aquaculture can be continued. As for the Nirwana I strain of tilapia, it showed a low polymorphism value $(<60 \%)$ and low heterozygosity, presumably as a result of the high level of inbreeding in this strain. The impact of the low level of genetic diversity, among others, is a decrease in the growth rate of the tilapia strain so that it is not recommended to be used as superior broodstock for the aquaculture.
\end{abstract}

KEYWORDS: Genetic evaluation; Oreochromis niloticus; RAPD; aquaculture centre

\footnotetext{
\# Korespondensi: Balai Riset Perikanan Budidaya Air Tawar dan

Penyuluhan Perikanan, Bogor

E-mail: sripudjisinarni@gmail.com
} 


\section{PENDAHULUAN}

Komoditas ikan nila menjadi salah satu komoditas utama dalam pembangunan perikanan budidaya dan ditargetkan dapat mendorong tercapainya program industrialisasi perikanan. Ketetapan tersebut didasarkan atas posisi Indonesia sebagai eksportir ikan nila pada peringkat kedua setelah Cina. Kebutuhan nila dalam bentuk fillet di pasar Amerika cukup besar, dan pasar potensial lainnya untuk ikan nila adalah Uni Eropa, Iran dan Rusia (Fitzsimmons, 2012; FAO, 2017).

Pasok ikan nila masih terkendala oleh produktivitas yang belum optimal dalam budidayanya. Oleh karena itu faktor kualitas perlu menjadi fokus yang layak untuk diperhatikan. Selain faktor itu, perbenihan ikan di tingkat nasional masih membutuhkan pembenahan secara sistematis. Faktor penting perbenihan akan berkembang dengan adanya strain-strain unggul ikan nila hasil pemuliaan yang dirilis secara resmi oleh Pemerintah. Beberapa strain yang telah dirilis antara lain ikan nila Nirwana I, nila Nirwana II, nila Nirwana III, nila Srikandi, nila Anjani, nila BEST, nila Larasati, nila Jatimbulan, dan semua strain ini merupakan hasil pemuliaan. Ikan strain unggul pada umumnya memiliki sifat-sifat yang menonjol dalam hal potensi hasil yang tinggi sehingga dapat meningkatkan produktivitas perikanan budidaya. Rilis jenis, introduksi, strain, maupun hibrida, merupakan rangkaian kegiatan formal dan merupakan tahapan penyerahan hasil dari pemulia kepada pemerintah dan masyarakat untuk dimanfaatkan secara optimal (Hadie et al., 2016).

Mengingat urgensi kualitas ikan nila yang berperan penting dalam produksi perikanan di tingkat nasional, maka diperlukan evaluasi kualitas genetik pasca rilis. Penelitian ini bertujuan untuk mengevaluasi kualitas genetik beberapa strain ikan nila setelah dimanfaatkan oleh masyarakat pembudidaya pada beberapa sentra produksi budidaya. Pendekatan genetik merupakan alat yang efektif untuk mengevaluasi status terkini dari sebuah populasi atau strain. Metode Random Amplified Polymorphic Dna (RAPD) merupakan teknik analisis berdasarkan amplifikasi reaksi rantai polimer pada daerah genom tertentu menggunakan primer oligonukelotida pendek. RAPD merupakan metode yang sederhana, cepat, dan sensitif dalam mengidentifikasi keragaman genetik tanpa harus terlebih dahulu mengetahui sekuens DNA nya (Almeida et al. 2001; Ganaie \& Ali, 2016) dan metode yang cocok untuk studi biologi DNA individu maupun populasi (Yoon \& Kim, 2004).

\section{BAHAN DAN METODE}

Koleksi Sampel

Sampel ikan uji diperoleh dari sentra budidaya ikan nila di Lombok, Nusa Tenggara Barat dan Purwakarta, Jawa Barat. Strain yang digunakan oleh pembudidaya ikan nila di Lombok adalah ikan nila Anjani dan ikan nila Nirwana I. Sedangkan strain ikan nila yang digunakan oleh pembudidaya di Purwakarta adalah ikan nila Nirwana III. Jumlah sampel untuk strain Nirwana III adalah 10 ekor, Nirwana I sebanyak 10 ekor, dan Anjani sebanyak 8 ekor. Sampel diambil dari potongan sirip ekor.

\section{Ekstraksi DNA dan Analisis RAPD}

Ekstraksi DNA dilakukan dengan menggunakan GSYNC-TM DNA Kit. Amplifikasi DNA dilakukan dengan metode PCR. Primer yang digunakan adalah OPA03, OPB06, OPZ09. Amplifikasi DNA dilakukan dengan menggunakan thermalcycler. Sampel yang sudah dibuat premix (hasil preparasi reagen) dimasukkan ke dalam mesin thermalcyler gradient karena menggunakan lebih dari 1 primer maka sampel diletakkan sesuai dengan suhu annealing setiap primernya. Amplifikasi DNA dilakukan pada kondisi pre-denaturasi pada suhu $94{ }^{\circ} \mathrm{C}$ selama 120 detik sebanyak 1 siklus; denaturasi pada suhu $94{ }^{\circ} \mathrm{C}$ selama 60 detik sebanyak 35 siklus; annealing untuk OPA 03 (5'- AGTCAGCCAC-3'), OPB 06 (5'- TGCTCTGCCC-3'), dan OPZ 09 (5'CACCCCAGTC $-3^{\prime}$ ) adalah 34,40 , dan $42^{\circ}$ Cselama 60 detik sebanyak 35 siklus, ekstension pada suhu $72^{\circ} \mathrm{C}$ selama 120 detik sebanyak 35 siklus, dan final ekstension pada suhu $72^{\circ} \mathrm{C}$ selama 420 detik sebanyak 1 siklus. Hasil PCR kemudian dielektroforesis menggunakan gel agarose $2 \%$ dalam Tris-Boric-EDTA (TBE) buffer. Hasil elektroforesis dimasukkan ke dalam GelDoc untuk divisualisasikan dan didokumentasikan. Foto hasil elektroforesis selanjutnya di-skoring menggunakan software AlphaView SA untuk mengukur berat molekul. Hasil skoring selanjutnya diubah ke data biner kemudian dilakukan analisis RAPD menggunakan software TFPGA (Tools for Population Genetic Analysis).

\section{HASIL DAN BAHASAN}

Profil amplifikasi DNA tergantung pada homologi sekuens nukleotida antara DNA templat dan primer oligonukletida pada setiap produk amplifikasi. Variasi nukleotida antara DNA templat yang berbeda akan menghasilkan ada atau tidaknya pita DNA karena perubahan situs penempelan primer. Oleh karena itu, produk amplifikasi dari alel yang sama dapat berbeda ukuran panjangnya dan akan dideteksi dengan ada/ tidaknya pita DNA pada profil RAPD (Ganaie \& Ali, 2016). Pada penelitian ini amplifikasi DNA yang menggunakan tiga primer (OPA-03, OPB-06, dan OPZ09) pada ikan nila strain Nirwana I, Nirwana III, dan Anjani menunjukkan bahwa DNA teramplifikasi pada setiap lokus dan bervariasi, masing-masing 
ditampilkan pada Gambar 1, 2, dan 3. Berdasarkan analisis RAPD didapatkan kisaran jumlah fragmen, ukuran fragmen, dan jumlah lokus per primer seperti tertera pada Tabel 1. Keragaman profil RAPD menunjukkan jumlah fragmen pada ketiga populasi berkisar 0-14 pita dengan ukuran fragmen DNA teramplifikasi berkisar antara $200-3000 \mathrm{bp}$.
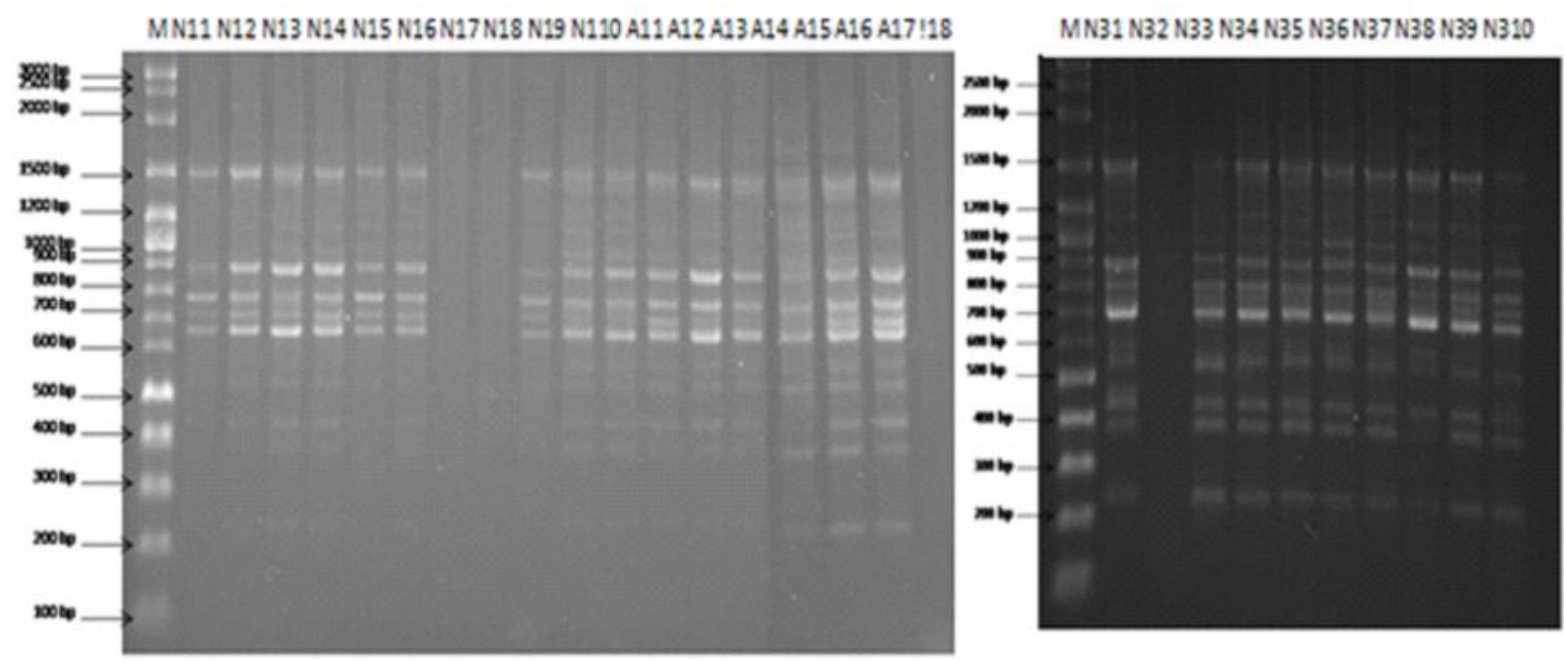

Gambar 1. Hasil amplifikasi DNA ikan nila strain Nirwana I, Anjani, dan Nirwana III menggunakan PCR-RAPD menggunakan primer OPA-03(Keterangan: $\mathrm{M}=$ Marker; N11 - N110 = sampel ikan nila Nirwana I; A1 - A8 = Anjani 1-8; N31-N310 = Nirwana III).

Figure 1. The result of DNA amplification for three strain of tilapia (Nirwana I, Anjani, and Nirwana III) analyzed by RAPD-PCR, using primer OPA-03 (M = marker; N11 - $110=$ Nirwana I; $A 1-A 8=$ Anjani 1-8; N31 - N310 = Nirwana III).

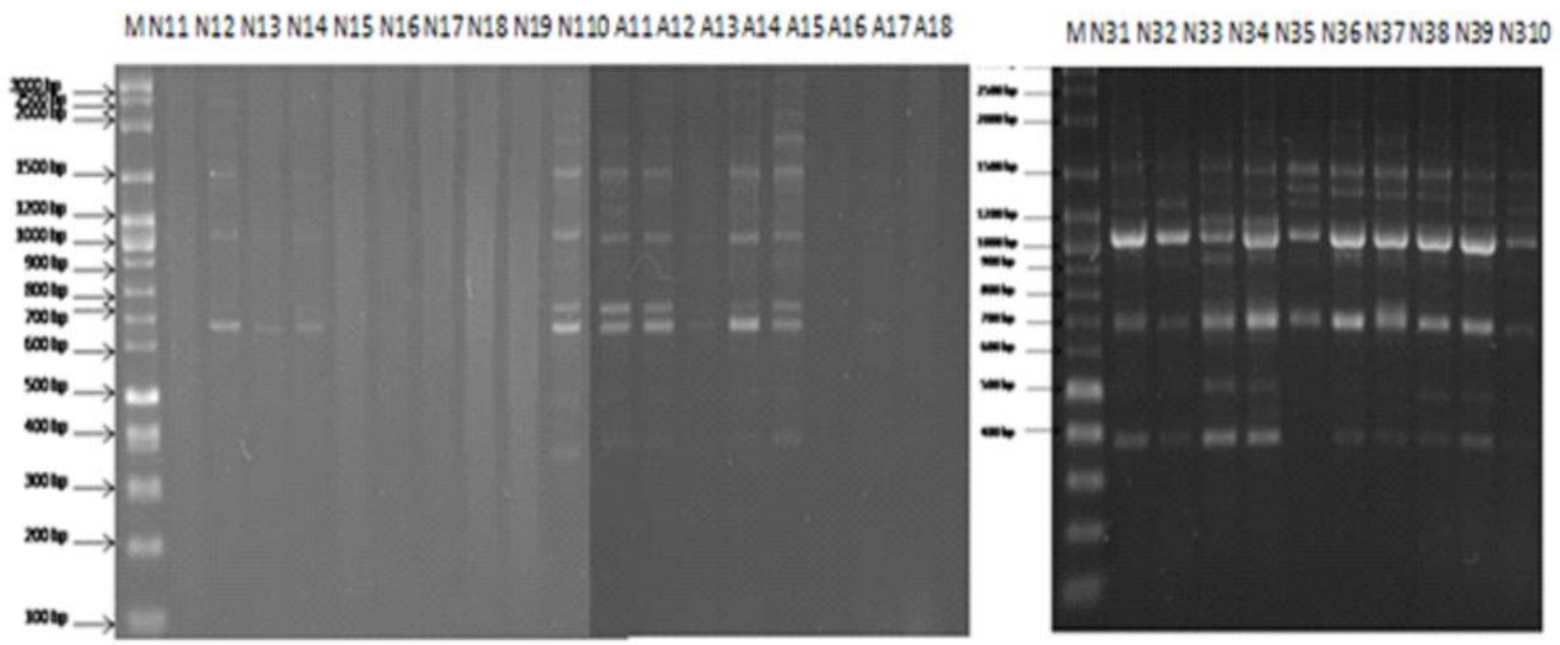

Gambar 2. Hasil amplifikasi DNA ikan nila strain Nirwana I, Anjani, dan Nirwana III menggunakan PCR-RAPD menggunakan primer OPB-06 (Keterangan: $\mathrm{M}=$ Marker; $\mathrm{N} 11$ - N110 = sampel ikan nila Nirwana I; A1 - A8 = Anjani 1-8; N31-N310 = Nirwana III).

Figure 2. The result of DNA amplification for three strain of tilapia (Nirwana I, Anjani, and Nirwana III) analyzed by RAPD-PCR method, using primer OPB-06 (M = marker; N11 - $110=$ Nirwana I; A1 A8 = Anjani 1-8; N31 - N310 = Nirwana III). 

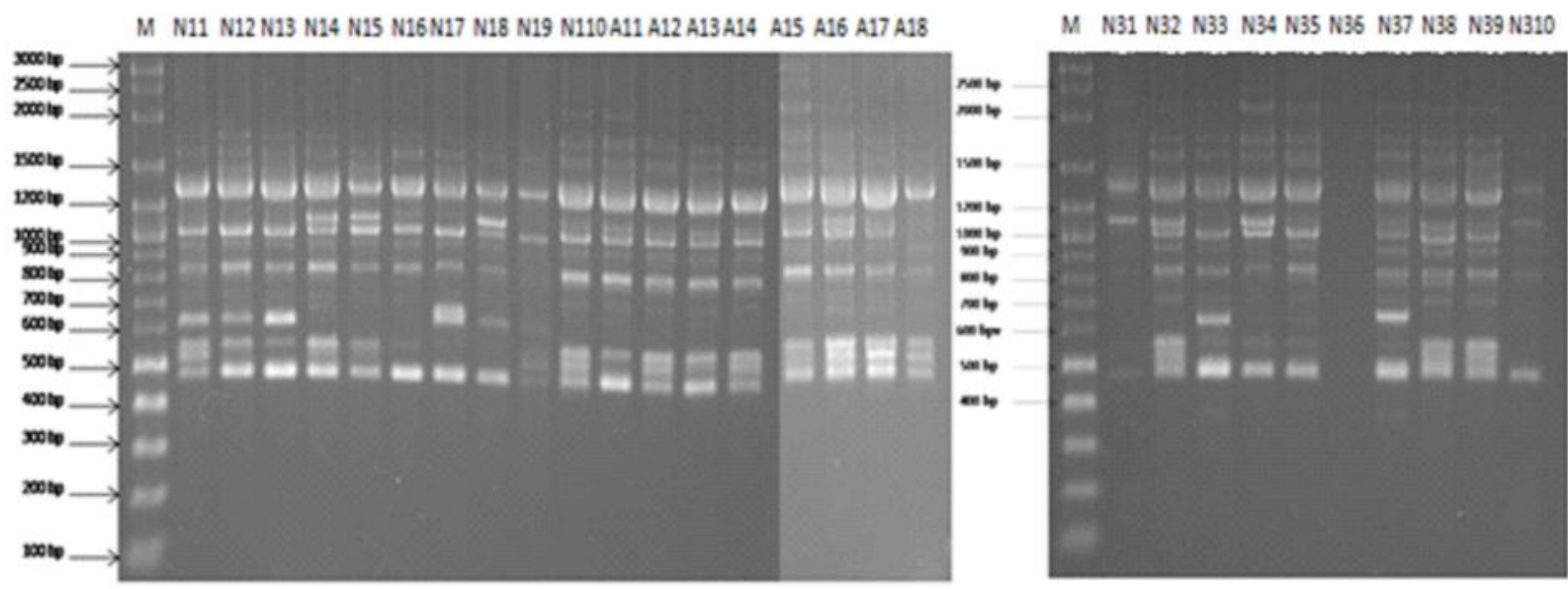

Gambar 3. Hasil amplifikasi DNA ikan nila strain Nirwana I, Anjani, dan Nirwana III menggunakan PCR-RAPD menggunakan primer OPZ-09 (Keterangan: $\mathrm{M}=$ Marker; N11 - N110 = sampel ikan nila Nirwana I; A1 - A8 = Anjani 1-8; N31-N310 = Nirwana III).

Figure 3. The result of DNA amplification for three strain of tilapia (Nirwana I, Anjani, and Nirwana III) analyzed by RAPD-PCR method, using primer OPZ-09 (M = marker; N11 - 110 = Nirwana I; A1 A8 = Anjani 1-8; N31 - N310 = Nirwana III).

Tabel 1. Kisaran jumlah fragmen DNA, ukuran fragmen DNA, dan jumlah lokus per primer pada ikan nila strain Nirwana I, Nirwana III, dan Anjani menggunakan primer OPA-03, OPB-06,dan OPZ-09

Table 1. The range of DNA fragment number, DNA fragment size, and locus number for each primer on three strain of tilapia (Nirwana I, Nirwana III, dan Anjani) by using primer OPA-03, OPB-06,dan OPZ-09

\begin{tabular}{|c|c|c|c|c|c|c|c|}
\hline \multirow[t]{2}{*}{ Primer } & \multicolumn{3}{|c|}{ Kisaran jumlah fragmen } & \multicolumn{3}{|c|}{ Kisaran ukuran fragmen } & \multirow{2}{*}{$\begin{array}{l}\text { Jumlah } \\
\text { lokus } \\
\text { per } \\
\text { primer }\end{array}$} \\
\hline & $\begin{array}{l}\text { Nirwana } \\
\text { III }\end{array}$ & $\begin{array}{l}\text { Nirwana } \\
\text { I }\end{array}$ & Anjani & $\begin{array}{l}\text { Nirwana } \\
\text { III }\end{array}$ & $\begin{array}{l}\text { Nirwana } \\
\text { I }\end{array}$ & Anjani & \\
\hline OPA 03 & $0-14$ & $0-13$ & $0-14$ & $200-2100$ & $\begin{array}{l}350- \\
2200\end{array}$ & $\begin{array}{l}200- \\
2000\end{array}$ & 22 \\
\hline OPB 06 & $5-9$ & $0-5$ & $0-11$ & 400-1900 & $\begin{array}{l}650- \\
2400\end{array}$ & $\begin{array}{l}350- \\
3000\end{array}$ & 23 \\
\hline OPZ 05 & $0-12$ & $7-11$ & $7-13$ & $350-2200$ & $\begin{array}{l}450- \\
1800\end{array}$ & $\begin{array}{l}400- \\
3000 \\
\end{array}$ & 23 \\
\hline $\begin{array}{l}\text { Total } \\
\text { kisaran } \\
\end{array}$ & $0-14$ & $0-13$ & $0-14$ & $200-2200$ & $\begin{array}{l}350- \\
2400 \\
\end{array}$ & $\begin{array}{l}200- \\
3000 \\
\end{array}$ & 68 \\
\hline
\end{tabular}

Polimorfisme dihitung berdasarkan skoring pada keberadaan pola amplifikasi fragmen pita DNA pada posisi spesifik yang diekspresikan dari beberapa polimer dekamer (Yoon \& Park, 2002). Pita polimorfisme yang dihasilkan dari proses RAPD-PCR dengan menggunakan beberapa jenis primer secara acak bermanfaat untuk mendeteksi similaritas DNA dan keragaman diantara organisme (Geng et al., 2002). Tingkat keragaman genetik suatu populasi ditentukan berdasarkan situs penempelan primer yang menghasilkan perbedaan polimorfisme pita DNA (Gusmiati et al., 2012; Gustiano et al., 2013). Perbedaan jumlah fragmen dan kisaran situs fragmen sangat menentukan tingkat polimorfisme. Persentase polimorfisme secara lengkap disajikan pada Tabel 2 . Persentase polimorfisme pada stain ikan nila Nirwana I, Nirwana III, dan Anjani secara berturut-turut adalah 47,06\%; 67,65\%; dan 70,59\%. Berdasarkan hasil yang diperoleh, populasi ikan nila strain Anjanidan Nirwana III memiliki nilai polimorfisme lebih dari $60 \%$, sedangkan strain Nirwana I menunjukkan nilai polimorfisme kurang dari 60\%. Menurut Kabir et al. (2017), tingkat polimorfisme yang kurang dari 60\%, seperti halnya pada strain Nirwana I, mengindikasikan rendahnya variasi genetik pada populasi tersebut, sehingga apabila akan dilakukan perbaikan kualitas genetik melalui program seleksi perlu ditambahkan sumber genetik baru untuk menghindari tekanan 
inbreeding. Ikan nila strain Anjani dan Nirwana III menunjukkan tingkat polimorfisme yang tinggi. Menurut Kusmini et al. (2011), tingginya tingkat polimorfisme pada suatu populasi menunjukkan efektivitas individu dalam proses seleksi (random mating) dan reproduksi di habitatnya.

Nilai heterosigositas pada populasi ikan nila Nirwana I, Nirwana III, dan Anjani secara berturutturut adalah 0,18; 0,24; dan 0,25 (Tabel 2). Heterozigositas merupakan ukuran keragaman genetik berdasarkan proporsi jumlah individu heterosigot populasi (Soewardi, 2007). Menurut Tave (1993), semakin tinggi heterosigositas maka semakin banyak gen yang terlibat dalam menyumbangkan tingkat kebugaran suatu populasi.Heterosigositas menunjukkan potensi kemampuan adaptasi terhadap lingkungannya, karena semakin tinggi heterosigositas maka semakin banyak gen yang terlibat dalam menyumbangkan tingkat kebugaran suatu populasi. Kondisi keragaman genetik dipengaruhi oleh ukuran populasi dan sistem pengembangbiakan yang dilakukan. Ukuran populasi yang besar dan persilangan bebas (acak) dapat mempertahankan keragaman genetik (Falconer dan MacKay, 1996). Sebaliknya ukuran populasi yang terbatas dan silang dalam dapat menyebabkan menurunnya keragaman genetik (Hallerman, 2003). Berdasarkan nilai heterigositas, ikan nila strain Nirwana I menunjukkan nilai terendah $(0,18)$ yang mengindikasikan adanya penurunan variasi genetik pada strain tersebut. Penurunan variasi genetik dapat disebabkan antara lain oleh penggunaan jumlah induk yang terbatas (Almeida et al. 2013).

Tabel 2. Nilai heterozigositas dan polimorfisme ikan nila strain Nirwana I, Nirwana III, dan Anjani

Table 2. Heterozygosity and polymorphism of three strain of tilapia (Nirwana I, Nirwana III, dan Anjani)

\begin{tabular}{lcc}
\hline Strain & Heterozigositas & Polimorfisme \\
\hline Nirwana III & 0.24 & 67.65 \\
Nirwana I & 0.18 & 47.06 \\
Anjani & 0.25 & 70.59 \\
\hline Antar populasi & 0.30 & 88.24 \\
\hline
\end{tabular}

Ikan nila Nirwana I, Anjani, dan Nirwana III merupakan induk unggul yang dihasilkan dari program selective breeding. Ikan nila Nirwana (Nila Ras Wanayasa) (Oreochromis sp.) dirilis pada Tahun 2006 berdasarkan SK Menteri Kelautan dan Perikanan Nomor KEP. 45/MEN/2006. Ikan nila Anjani dirilis pada Tahun 2012 berdasarkan SK Menteri Kelautan dan Perikanan Nomor KEP. 46/MEN/2012. Ikan nila Nirwana III dirilis pada Tahun 2016 berdasarkan SK Menteri Kelautan dan Perikanan NOMOR 28/KEPMEN-KP/2016. Peredaran ikan nila Nirwana I di masyarakat pembudidaya relatif lebih lama dibandingkan dua strain lainnya, dan berdasarkan estimasi umur reproduksi optimalnya, generasi ikan nila Nirwana I yang beredar saat ini sudah mencapai lebih dari 5 generasi. Pada beberapa unit pembenihan rakyat (UPR) ikan nila yang ada di Lombok, jumlah induk ikan nila Nirwana I yang digunakan di tingkat UPR umumnya terbatas. Selain itu induk yang digunakan juga merupakan keturunan tanpa melalui program seleksi, sehingga diduga terjadi inbreeding yang menyebabkan penurunan kualitas genetik. Pada ikan nila Nirwana III dan Anjani, manajemen induk masih dilakukan oleh institusi yang menghasilkannya yaituBalai Pengembangan Budidaya Ikan Nila dan Mas, Wanayasa, Dinas Perikanan dan Kelautan Propinsi Jawa Barat dan UPTD Balai Pengembangan Budidaya Ikan Air Tawar, Aikmal, Nusa Tenggara Barat. Penggunaan jumlah induk yang mencukupi didukung oleh ketersediaan sarana, prasarana, dan sumberdaya yang memadai, menjadi faktor pendukung terjaganya keunggulan kualitas genetik ikan nila Nirwana III dan Anjani.

\section{KESIMPULAN}

Tingkat heterosigositas dan polimorfisme ikan nila strain Anjani dan Nirwana III yang beredar di masyarakat menunjukkan nilai yang tinggi, sehingga masih dapat digunakan sebagai induk/benih unggul. Adapun pada ikan nila strain Nirwana I menunjukkan nilai heterosigositas dan polimorfisme yang rendah yang mengindikasikan adanya penurunan variasi genetik sebagai akibat adanya tekanan inbreeding atau manajemen induk yang kurang baik sehingga direkomendasikan untuk tidak digunakan sebagai induk unggul di masyarakat.

\section{UCAPAN TERIMA KASIH}

Penelitian ini dibiayai oleh Anggaran Pusat Riset Perikanan, Badan Riset Kelautan dan Perikanan, Kementerian Kelautan dan Perikanan. Ucapan terima kasih disampaikan kepada Kepala Dinas Perikanan Nusa Tenggara Barat dan Kepala Balai Pengembangan Budidaya Ikan Wanayasa Jawa Barat, atas data dan informasi yang diberikan. 


\section{DAFTAR PUSTAKA}

Almeida, F.S., Fungaro, M.H.P., Sodre, L.M.K. (2001). RAPD and isoenzyme analysis of genetic variability in three allied species of catfish (Siluriformes: Pimelodidae) from the Tibagi River, Brazil, Journal of Zoology, 253( 1), 113-120.

Almeida, F.S., Lopes, C.M., Orsi, M.L., Sirol, R.N., Sodre, L.M.K. (2013). Genetic monitoring by RAPD markers for repopulation programs of Salminus brasiliensis (Pices, Characiformes). 2013, Acta Scientiarum, 35(2),119-126.

FAO. (2017). International demand for tilapia steady, though US market weak with discouraging prices.GLOBEFISH-Analysis and information of world fishtrade.http://www.fao.org/in-action/ globefish/market-report/resource-detail/en/c/ 107669.

Falconer,F.S. and MacKay, T.F.C. (1996). Introduction to Quantitative Genetics, 464. Longman, England.

Fitzsimmons, K. (2012). The success story of tilapia industry; current and future trends of the US seafood market. Nong Lam University - Ho Chi Minh. Vietnam presentation in 28 June 2012.

Ganaie, H.A. \& Ali, M.N. (2016). Studies on the genetic variability of three fish species (Cyprinus carpio specularis, Cyprinus carpio communis and Onchorhynchus mykiss) collected from Kashmir (India) using random amplified polymorphic DNA (RAPD) technique), Asian Journal of Animal Sciences, 10(1),59-67.

Geng, S. M., W. Shen, G. Q. Qin, X. Wang, S. R. Hu, Q. Wang and J. Q. Zhang. (2002). DNA fingerprint polymorphism of 3-goatpopulations from China Chaidamu Basin. Asian-Aust, Journal of Animal Science, 15 (8), 1076-1079.

Gusmiati, Restu, M., \& Pongtuluran. (2012). Seleksi primer untuk analisa keragaman genetik jenis bitti (Vites coffassus), Jurnal Perennial, 8, 25-29.

Gustiano, R., Oktaviani, T., Soelistyowati, D.T., Kusmini, I.I., Wahyutomo, Huwoyon, G.H. (2013). Analisis ragam genotip RAPD dan fenotip truss morfometrik pada tiga populasi ikan gabus [Channa striata (Bloch, 1793)], Berita Biologi, 12(3),325333.

Hadie, W., Rasidi, Hadie, L.E. (2016). Implementasi dan evaluasi dampak rilis varietas ikan terhadap peningkatan produksi perikanan, Prosiding Forum Inovasi Teknologi Akuakultur 2016, 69 - 80.

Hallerman, E.M. (2003). Population Genetics: Principles and Applications for Fisheries Scientist, 458. American Fisheries Society. University of California, USA.

Kabir, Md. A., Rahman, M.S., Begum, M., Faruque, Md., H. (2017). Genetic diversity by RAPD in four populations of rohu Labeo rohita, Croatian Journal of Fisheries, 75,12-17.

Kusmini, I.I., Gustiano, R., \& Mulyasari. (2011). Karakterisasi genetik ikan Kelabau (Osteochilus kelabaul) dari berbagai lokasi di Kalimantan Barat menggunakan analisis RAPD, Berita Biologi, 10(4), 449-454.

Soewardi, K. (2007). Pengelolaan keragaman genetik sumber daya perikanan dan kelautan. Departemen Manajemen Sumberdaya Perairan. Institut Pertanian Bogor. Bogor. $153 \mathrm{hlm}$.

Tave, D. (1993). Genetics for Fish Hatchery Managers, 415. Kluwer Acad. Publ. Netherland.

Wasko, A.P. \& Galleti Jr., P.M. (2002). RAPD analysis in the neutropical fish Brycon lundii: genetic diversity and its implications for the conservation of the species, Hydrobiologia, 474,131-137.

Yoon, J. M. and H. Y. Park. (2002). Genetic similarity and variation in the cultured and wild crucian carp (Carassius carassius) estimated with random amplified polymorphic DNA, Asian - Australian Journal of Animal Science, 15 (4), 470-476.

Yoon, J.M. \& Kim, J.Y. (2004). Genetic differences within and between populations of Korean catfish (S. Asotus) and bullhead (P. Fulvidraco) analysed by RAPD-PCR, Asian - Australian Journal of Animal Science, 17(8),1053-1061. 